\title{
Quantitative relationships of Pseudomonas chlororaphis 63- 28 to Pythium root rot and growth in hydroponic peppers
}

\author{
Coralie R. Sopher \& John C. Sutton \\ School of Environmental Sciences, University of Guelph, Guelph, Ontario, N1G 2W1, Canada. \\ Author for correspondence: Coralie Sopher, email: csopher@uoguelph.ca
}

\begin{abstract}
The ability of Pseudomonas chlororaphis 63-28 to suppress Pythium root rot (Pythium aphanidermatum) and promote plant growth was investigated in hydroponic peppers that were predisposed or not predisposed to the disease. The biocontrol agent was introduced into the nutrient solution 10 days before the roots were inoculated with the pathogen. The root zone was maintained at $23^{\circ} \mathrm{C}$ except when roots were exposed to $33^{\circ} \mathrm{C}$ for three days before inoculation to induce predisposition to root rot. At constant $23^{\circ} \mathrm{C}$ (no

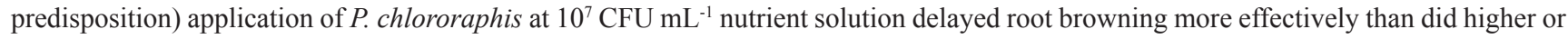
lower densities. In predisposed plants, densities of $10^{6}, 10^{7}$ and $10^{8} \mathrm{CFU} \mathrm{mL} \mathrm{me}^{-1}$ were equally superior. When applied at $10^{7} \mathrm{CFU} \mathrm{mL}^{-1}$, the density of $P$. chlororaphis on roots of the two temperature regimes ranged from $\log _{10} 5.88$ to $6.45 \mathrm{CFU} \mathrm{g}^{-1}$ fresh roots at seven to 19 days after application. The agent delayed root browning, re-mediated predisposition to root rot, and increased growth of inoculated and noninoculated plants. Leaf expansion was a sensitive marker of root rot and remediation by P. chlororaphis. We conclude that P. chlororaphis 63-28 has substantial potential for managing the disease regardless of predisposition.
\end{abstract}

Key words: Capsicum annuum, Pythium aphanidermatum, disease predisposition, biological control, leaf expansion.

\section{RESUMO}

Relações quantitativas de Pseudomonas chlororaphis 63-28 com a podridão radicular causada por Pythium e ao crescimento de pimentão hidropônico

A supressão da podridão de raiz (Pythium aphanidermatum) e a promoção de crescimento de pimentão hidropônico por Pseudomonas chlororaphis 63-28 foram avaliadas em plantas predispostas ou não ao patógeno. O bioagente foi introduzido na solução nutritiva 10 dias antes das raízes serem inoculadas com o patógeno. A zona radicular foi mantida a $23^{\circ} \mathrm{C}$, exceto nos três dias antes da inoculação quando as plantas foram expostas a $33^{\circ} \mathrm{C}$. Na temperatura de $23^{\circ} \mathrm{C}$ (sem predisposição), P. chlororaphis na concentração de $10^{7} \mathrm{UFC} \mathrm{mL} \mathrm{mL}^{-1}$, aplicada na solução nutritiva, atrasou o aparecimento dos sintomas da doença. As concentrações de $10^{6}, 10^{7}$ e $10^{8} \mathrm{UFC}$ $\mathrm{mL}^{-1}$ do bioagente foram mais eficientes em controlar a doença nas plantas inoculadas com o patógeno. A densidade do bioagente nas raízes, nos dois regimes de temperatura, variou de 5,88 a 6,45 log da UFC g ${ }^{-1}$ de raiz fresca, do sétimo ao $19^{\circ}$ dia após a aplicação de $10^{7}$ UFC $\mathrm{mL}^{-1}$ Nas plantas inoculadas ou não, o bioagente atrasou o aparecimento do escurecimento radicular, remediou a predisposição a doença e incrementou o desenvolvimento das plantas. A expansão foliar foi um indicador adequado para a podridão de raiz e a remediação com P. chlororaphis. Conclui-se que P. chlororaphis 63-28 tem potencial para o manejo da podridão da raiz em sistemas hidropônicos, independentemente da predisposição.

Palavras-chave: Capsicum annuum, Pythium aphanidermatum, controle biológico, expansão foliar, predisposição a doença.

\section{INTRODUCTION}

Sweetpeppers (Capsicumannuum L.) are producedall year round in Ontario greenhouses by means of sophisticated hydroponic systems. The pepper plants are normally grown in slabs of rock wool or coconut fiber, or in troughs, through which plant nutrient solution is continuously re-circulated. The solution is discharged from the root zone into mixing tanks, in which the nutrient composition, $\mathrm{pH}$, and oxygen level are regulated, and subsequently returned to the root zone. Heavy and sustained productivity of marketable fruit during the crop cycle is paramount for pepper crops to be competitive and profitable, but is frequently compromised by the development of Pythium root rot. In Ontario, root rot is caused primarily by Pythium aphanidermatum
(Edson) Fitzp. and is characterized by browning (necrosis) and fragmentation of the roots (Owen-Going et al., 2003; Sutton et al., 2006). Severe root rot often develops in commercial crops during or following periods of warm or sunny weather when the root zone temperature is high (e.g. 28 to $34^{\circ} \mathrm{C}$ ) (Sutton et al., 2006). Sopher \& Sutton (2009) confirmed that high root-zone temperature favors rapid development of root rot and found that roots of healthy peppers were predisposed to early and severe root browning when exposed to $33^{\circ} \mathrm{C}$ for nine to $144 \mathrm{~h}$ and subsequently inoculated with $P$. aphanidermatum.

Colonization of pepper roots by $P$. aphanidermatum is normally biotrophic at first and subsequently necrotrophic (Sutton et al., 2006). The biotrophic phase, during which the roots generally remain whitish and symptomless, is 
frequently prolonged (e.g. several weeks) and sometimes indefinite when the root zone is cool (e.g. 16 to $20^{\circ} \mathrm{C}$ ), but the transition to necrotrophy (root browning) occurs within days or even hours at higher temperatures (e.g. 24 to $34^{\circ} \mathrm{C}$ ) (Sutton et al., 2006). Growth and productivity of peppers and other plants are usually reduced after the roots turn brown, but not in the biotrophic phase. Ortiz-Uribe (2007) found that root and shoot growth of hydroponicallygrown snapdragons abruptly and markedly declined at the onset of the necrotrophic phase of Pythium root rot. Taken together, available information indicates that control of root browning is critical for maintaining high productivity in $P$. aphanidermatum-infected crops, but effective and practical methods to achieve this are lacking.

Root-zone temperatures that are sufficiently cool to control root browning are sub-optimal for pepper growth and in many instances difficult and prohibitively expensive to maintain. Beneficial microbes are potential means for controlling root rot, but have received only limited attention in hydroponic peppers (Corrêa \& Bettiol, 2009). Several workers (e.g. McCullagh et al., 1996; Sutton et al., 2008) concluded that certain microbial agents have value for enhancing the growth and productivity of healthy as well as diseased crops and justify development as plant inoculants. Microbial treatments also have the potential to satisfy safety requirements for greenhouse employees, consumers, and the environment.

Microbes were reported to suppress Pythium root rot caused by $P$. aphanidermatum in several kinds of hydroponic crops, notably cucumbers, chrysanthemums, tomatoes, and lettuce (Corrêa \& Bettiol, 2009; Corrêa et al., 2010). Those with superior effectiveness included strains of Bacillus subtilis, Bacillus cereus, Streptomyces griseoviridis, Pseudomonas fluorescens, Pseudomonas corrugata, Pseudomonas chlororaphis, Comomonas acidovorans, Clonostachys rosea, and Trichoderma harzianum (Rankin \& Paulitz, 1994; McCullagh et al., 1996; Paulitz \& Bélanger, 2001; Zheng et al., 2000; Liu et al., 2003; Liu et al., 2007). Strains of Pseudomonas chlororaphis (= Pseudomonas aureofaciens) (Johnson \& Palleroni, 1989) strongly suppressed $P$. aphanidermatum in roots of pepper, cucumber, chrysanthemum and snapdragon in small-scale hydroponic systems and P. chlororaphis generally performed better than isolates of other microbes (Chatterton, 2002; Chatterton et al., 2004; Khan et al., 2003; Liu et al., 2007). Pseudomonas chlororaphis strains TX-1 and 63-28 (Turf Science Laboratories, National City, CA, USA) were of similar effectiveness in suppressing root rot caused by $P$. aphanidermatum in chrysanthemums grown in single-plant hydroponic units in a greenhouse at 22 to $25^{\circ} \mathrm{C}$, and also performed well against the pathogen when the root zone temperature was high $\left(32^{\circ} \mathrm{C}\right)$ (Liu et al., 2007). Liu et al. (2007) further found that P. chlororaphis strain 63-28, but not strain TX-1, was effective against chrysanthemum root rot caused by Pythium dissotocum, which was reported as a pathogen on hydroponic peppers in Ontario (Owen-
Going et al., 2003). Pseudomonas chlororaphis 63-28 suppressed Pythium root rot and promoted shoot growth more effectively than did other agents in vegetative-stage cucumbers grown in greenhouse hydroponic systems (Liu et al., 2003). McCullagh et al. (1996) found that the number of fruit produced over time in cucumbers inoculated with $P$. aphanidermatum was greater in plants treated with $P$. fluorescens 63-28 (= P. chlororaphis 63-28) compared to untreated plants, but found no significant effect on yield when disease severity was low or absent. Gagné et al. (1993) reported that P. fluorescens 63-28 substantially increased the total fruit yield and percentage of marketable fruit of tomatoes grown in peat-based media amended with the bacterium prior to planting, compared to plants grown in non-amended media. Taken together, the reports suggest that $P$. chlororaphis 63-28 justifies further investigation for dual activity as an inoculant to enhance productivity of pepper crops in which little or no disease is present and as an agent to suppress Pythium root rot. Findings that high root zone temperature predisposes pepper plants to Pythium root rot (Sopher \& Sutton, 2009) underscore the need to examine effectiveness of treatments in predisposed as well as non-predisposed plants.

The objectives of the present investigations in hydroponically-grown peppers were: $i$. to determine relationships of inoculum density of $P$. chlororaphis 6328 applied in the nutrient solution to progress of root browning caused by $P$. aphanidermatum; ii. to determine the optimum density of $P$. chlororaphis 63-28 inoculum for root rot control; iii. to examine densities of $P$. chlororaphis 63-28 associated with the roots as a function of time after application, root zone temperature regimes, and inoculation with $P$. aphanidermatum; iv. to examine quantitative effects and interactions of $P$. chlororaphis 63-28, root-zone temperature regimes, and $P$. aphanidermatum on growth parameters of vegetative peppers; v. to assess leaf expansion as a minimally intrusive means to estimate effectiveness of P. chlororaphis 63-28 against root rot.

\section{MATERIAL AND METHODS}

\section{Hydroponic pepper plants}

Plants of sweet pepper cv. Cubico (De Ruiter Seeds Inc., Columbus, OH, USA) were grown on a bench in a growth room as described by Sopher \& Sutton (2009). In brief, 5-week old seedlings in rock wool plugs $(2.5 \mathrm{~cm} \mathrm{X}$ $2.5 \mathrm{~cm}$ X $4.0 \mathrm{~cm}$; Grodan, Roermond, The Netherlands) were placed in 5-cm diameter mesh pots and transferred to single-plant hydroponic units. Each unit comprised a 475 $\mathrm{mL}$ white polyethylene container with a lid in which a hole was made to accommodate the mesh pot and plant. The container was filled with plant nutrient solution that was aerated continuously by means of a bubbler. When used for experiments, plants were initially $9-11 \mathrm{~cm}$ tall with roots that extended $8-10 \mathrm{~cm}$ below the rock wool plugs into the nutrient solution. The air temperature in the growth room 
was $23-24^{\circ} \mathrm{C}$ and the intensity of photosynthetically active radiation (PAR) at plant height was $180-200 \mu \mathrm{mol} / \mathrm{m}^{2} / \mathrm{s}$ as measured by quantum sensors (Q 3991-4 LI-COR Inc., Lincoln, NE, USA).

\section{Control of high root zone temperature}

The hydroponic units were placed in temperaturecontrolled water baths to control root zone temperature as described by Sopher \& Sutton (2009). The baths were positioned on the bench in the growth room.

\section{Inoculum production and application of Pseudomonas chlororaphis}

Pseudomonas chlororaphis strain 63-28 was used in all experiments. For long-term storage, cells were suspended in glycerol:tryptic soy broth (TSB) (30:70) and kept in $1 \mathrm{~mL}$ microfuge tubes at $-20^{\circ} \mathrm{C}$ and $-70^{\circ} \mathrm{C}$. The bacterium was recovered on tryptic soy agar medium (TSA) at $22^{\circ} \mathrm{C}$ for $48 \mathrm{~h}$ and subsequently grown in TSB in Erlenmeyer flasks on a gyratory shaker (Model G2, New Brunswick Scientific, Edison, NJ, USA) operated at $100 \mathrm{rpm}$. For tests on pepper plants, 24-h TSB cultures were centrifuged under refrigeration at $3000 \mathrm{x} \mathrm{g}$ for $15 \mathrm{~min}$. Recovered cells were washed twice and resuspended in $0.1 \mathrm{M} \mathrm{MgSO}_{4}$. The density of suspended cells was estimated from absorbance values obtained at $600 \mathrm{~nm}$ on a spectrophotometer (model PU8620, Philips, Cambridge, UK) and a standard curve of absorbance vs. cell density. Cells were centrifuged again, suspended in nutrient solution at a density of $1 \times 10^{9}$ colony forming units (CFU) $\mathrm{mL}^{-1}$ and applied into the nutrient solution of the hydroponic units 10 days before the roots were inoculated with $P$. aphanidermatum. The final density of $P$. chlororaphis in the nutrient solution of the units was 1 $\mathrm{X} 10^{7} \mathrm{CFU} \mathrm{mL}^{-1}$ unless otherwise indicated.

\section{Pythium inoculum and inoculations}

The protocols used for maintenance and growth of $P$. aphanidermatum and for inoculating pepper roots were described by Sopher \& Sutton (2009). In summary, the pathogen was maintained on root tissue, re-isolated on a Pythium-selective agar medium, and induced to sporulate in Petri dishes containing V8 agar medium. For inoculations, each plant was lifted from its hydroponic unit, positioned in a metal tray with all roots immersed in an aqueous suspension of $5 \times 10^{3}$ zoospores $\mathrm{mL}^{-1}$ for $30 \mathrm{~min}$, and returned to the unit.

\section{Density of Pseudomonas chlororaphis in roots}

Numbers of $P$. chlororaphis cells associated with pepper roots were estimated by grinding composite 1-g root samples in $10 \mathrm{~mL}$ aliquots of $0.1 \mathrm{M} \mathrm{MgSO}_{4}$ using sterilized mortars and pestles. The samples included roots of all orders and depths in the hydroponic units. Suspensions of the ground tissues were serially diluted, spread onto TSA medium in Petri dishes, and incubated at $25^{\circ} \mathrm{C}$ for $48-72 \mathrm{~h}$. Colony counts were used to estimate $\mathrm{CFU} \mathrm{g}{ }^{-1}$ fresh roots.

\section{Root colonization by Pythium and root discoloration}

To estimate percent roots colonized by $P$. aphanidermatum, roots were detached at random from each plant and cut into $1-\mathrm{cm}$ long segments. The segments were surface disinfested in $1 \% \mathrm{NaOCl}$ for $30 \mathrm{~s}$ and in $70 \%$ ethanol for $30 \mathrm{~s}$, rinsed three times in sterile distilled water and blotted dry. Thirty random root segments from each plant were placed on the Pythium-selective medium, incubated at $25^{\circ} \mathrm{C}$ for $48 \mathrm{~h}$, and assessed for incidence of $P$. aphanidermatum. For estimating root discoloration, each plant was lifted above the nutrient solution and the roots were examined with the aid of a six-cm diameter hand lens (10X magnification). The percent of roots that were discolored was estimated using an equal-increment scale of $0-10(0=0 \%, 1=1-10 \%, 2=11-20 \% \ldots .10$ $=91-100 \%)$. Discoloration was usually gray-brown or reddish-brown. Mid-point values of scale increments were used for data analysis.

\section{Plant growth analysis}

In destructive harvests, the height of each plant was measured from the rock wool plug to the highest point of the apical cluster of leaves, and the shoots were removed and immediately weighed to determine fresh mass. All leaves were detached and an area meter (model LI-3000, LI-COR, Lincoln, NE, USA) was used to measure total leaf area per plant. All roots exterior to the rock wool cube were removed, blotted dry and weighed to determine fresh mass. To determine dry mass values, the shoots (stems plus leaves) and roots were dried to constant weight at $80^{\circ} \mathrm{C}$ for $48 \mathrm{~h}$ in a drying oven and weighed.

\section{Experiment 1: Progress of Pythium root rot in relation to density of $P$. chlororaphis \\ Pseudomonas chlororaphis was applied into the} nutrient solution of the hydroponic units at final densities of $0,10^{4}, 10^{5}, 10^{6}, 10^{7}$, and $10^{8} \mathrm{CFU} \mathrm{mL}^{-1}$. After seven days at $23^{\circ} \mathrm{C}$, the temperature of the nutrient solution of half of the treated plants and half of the untreated plants was raised to $33^{\circ} \mathrm{C}$ for three days to predispose the plants to root rot (Sopher \& Sutton, 2009) and subsequently cooled to $23^{\circ} \mathrm{C}$. The solution of the remaining plants was constant at $23^{\circ} \mathrm{C}$ (no predisposition). Plants of each $P$. chlororaphis treatment in each temperature regime were inoculated or not inoculated with $P$. aphanidermatum 10 days after $P$. chlororaphis was applied. The nutrient solution of high temperature treatments was cooled to $23^{\circ} \mathrm{C}$ before roots were inoculated. Root discoloration was estimated immediately before the plants were treated with $P$. chlororaphis, immediately before the pathogen was introduced into the root zone, and each day thereafter for 12 days. 
Experiment 2: Density dynamics of Pseudomonas chlororaphis in the roots as a function of time after application in the root zone, root zone temperature, and root inoculation with Pythium aphanidermatum

The nutrient solution of hydroponic pepper plants was treated with $P$. chlororaphis at a final density of 1 $\mathrm{X} 10^{7} \mathrm{CFU} / \mathrm{mL}$ or not treated. Root zone temperatures, pathogen inoculations, and the method used to estimate root discoloration were the same as in experiment 1 . Root colonization by $P$. aphanidermatum was estimated at 0,3 , $6,9,12,15,24,36$ and $48 \mathrm{~h}$ after inoculation. Density of P. chlororaphis associated with the roots was estimated immediately before and after the time of the high temperature predisposition treatment, and at three, six and nine days after roots were inoculated with the pathogen (respectively 7, 10, 13, 16, and 19 days after $P$. chlororaphis was applied into the nutrient solution).

Experiment 3. Effects of Pseudomonas chlororaphis, root zone temperature, and root inoculation with Pythium aphanidermatum on plant growth parameters

Plants were treated with $P$. chlororaphis 6328 , exposed to high temperature and inoculated with $P$. aphanidermatum as described for experiment 2. Plant growth analyses (described above) were performed immediately before $P$. chlororaphis 63-28 was applied in the nutrient solution, immediately before roots were inoculated with $P$. aphanidermatum, and at three, six, nine and 12 days after inoculation.

Experiment 4: Effects of Pseudomonas chlororaphis, root-zone temperature, and root inoculation with Pythium aphanidermatum on leaf expansion

Plants were treated with $P$. chlororaphis, exposed to high temperature and inoculated with $P$. aphanidermatum as described for experiment 2. A young attached leaf just below the shoot apex of each plant (leaf 12 from the base of the stem) was tagged immediately before $P$. chlororaphis was applied in the nutrient solution, and its area was measured immediately and daily thereafter. For area measurements, the leaf margin was traced onto a transparent photocopy sheet and the traced outline was excised and weighed. Leaf area was estimated from a linear standard curve for sheet area in relation to weight $\left(\mathrm{r}^{2}=0.9997\right)$. In a preliminary study conducted under the same conditions no significant difference ( $\mathrm{P}=0.05)$ was found between the ratio of leaf area to leaf weight of healthy plants compared to plants with $60-80 \%$ root rot.

\section{Experimental design and statistical analysis}

In all instances the experimental unit was a single plant in a hydroponic unit. Each experiment was designed as a randomized complete block and repeated three times. Trends in data of experimental repetitions were similar, and in each instance data of one repetition are presented. There were four replicate plants per treatment in experiments 1,3 and 4 and three in experiment 2. Data were analyzed with SAS software Version 9.1 (SAS Institute Inc. Cary, N.C., USA) using the ANOVA and LSD $(p=0.05)$ procedures for separation of treatment means.

\section{RESULTS}

Experiment 1: Progress of Pythium root rot in relation to density of Pseudomonas chlororaphis

Roots of the two temperature treatments that were treated or not treated with $P$. chlororaphis and not inoculated with $P$. aphanidermatum appeared whitish and remained free from $P$. aphanidermatum throughout the experiment. Roots not treated with $P$. chlororaphis, but inoculated with the pathogen, turned brown approximately three days earlier when exposed to $33^{\circ} \mathrm{C}$ for three days prior to inoculation (i.e. roots predisposed to root rot) compared to those kept at a constant $23^{\circ} \mathrm{C}$ (not predisposed) (Figure 1). After onset, root browning in both instances progressed from 0 to $100 \%$ during seven to eight days. Application of $P$. chlororaphis at $10^{4} \mathrm{CFU} \mathrm{mL} \mathrm{mu}^{-1}$ nutrient solution had little or no effect on root browning, but application at $10^{5} \mathrm{CFU} \mathrm{mL}^{-1}$ delayed browning by about two days in plants of each temperature treatment. When applied at respective final densities of $10^{6}, 10^{7}$ and $10^{8} \mathrm{CFU} \mathrm{mL}^{-1}, P$. chlororaphis delayed initial browning by four, four, and three days in roots at a constant $23^{\circ} \mathrm{C}$, and in each instance by six days in roots exposed to $33^{\circ} \mathrm{C}$, prior to inoculation with $P$. aphanidermatum. Slopes of the root browning curves that reached 95-100\% during the experiment, calculated based on the initial five values exceeding zero, did not differ significantly. Linear equations for the slopes ranged from $Y=16.8 x-57.6$ to $Y=18 x-112.8$.

Experiment 2: Density dynamics of Pseudomonas chlororaphis in the roots as a function of time after application in the root zone, root zone temperature, and root inoculation with Pythium aphanidermatum

Roots of the two temperature regimes that were treated or not treated with $P$. chlororaphis and not inoculated with $P$. aphanidermatum appeared whitish throughout the experiment. The pathogen was not recovered from non-inoculated roots. Incidence of recovery of $P$. aphanidermatum from segments of inoculated roots was $0 \%$ for samples taken at zero or three $\mathrm{h}$ after inoculation, respectively $12 \%, 46 \%$ and $70 \%$ for samples taken at six, nine and twelve hours, and $100 \%$ for subsequent samples. Pathogen incidence did not differ significantly $(\mathrm{P}=0.05)$ for roots that were treated or not treated with $P$. chlororaphis, or for roots of the two temperature regimes.

A mean density of $\log 6.42 \mathrm{CFU}$ of $P$. chlororaphis $\mathrm{g}^{-1}$ roots was found seven days after the agent was applied into the nutrient solution (i.e. when high temperature predisposition treatments were initiated) (Figure 2). At 10 days after application (i.e. immediately before roots were inoculated with $P$. aphanidermatum) density of P. chlororaphis ranged from $\log 6.38$ to $6.45 \mathrm{CFU} \mathrm{g}^{-1}$ 


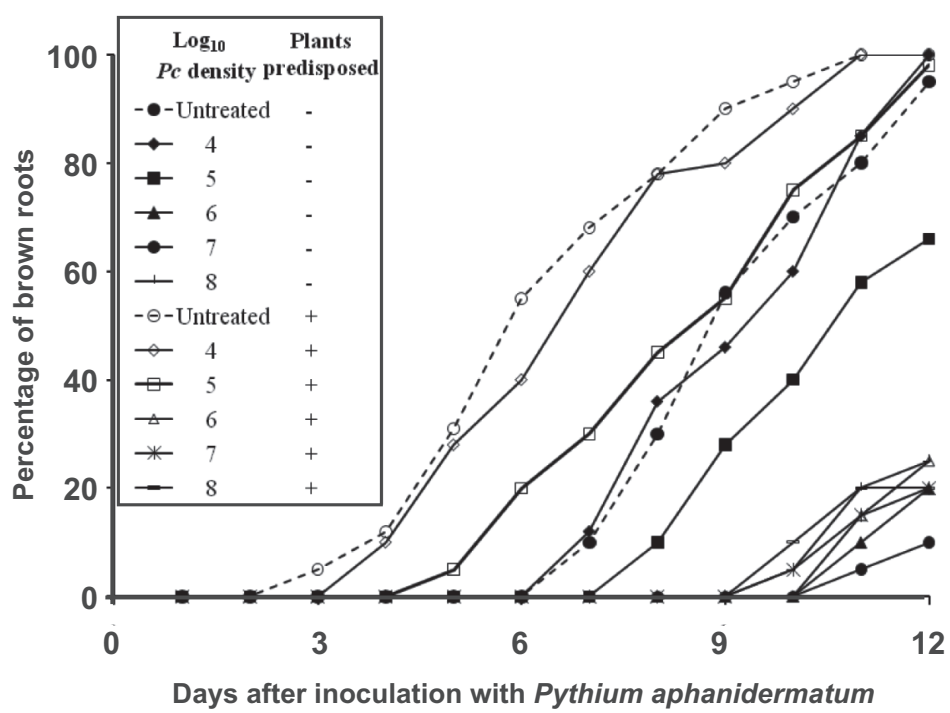

Days after inoculation with Pythium aphanidermatum
FIGURE 1 - Root browning progress curves in hydroponic pepper plants inoculated with Pythium aphanidermatum $(\mathrm{Pa})$ as a function of density of Pseudomonas chlororaphis 63$28(P c)$ applied in the nutrient solution and high temperature predisposition of the plants to Pythium root rot. $P c$ was applied 10 days before the roots were inoculated with $P a$. The root zone was maintained at $23^{\circ} \mathrm{C}$ for non-predisposed plants but the temperature was increased to $33^{\circ} \mathrm{C}$ for three days prior to inoculation to predispose plants to root rot.

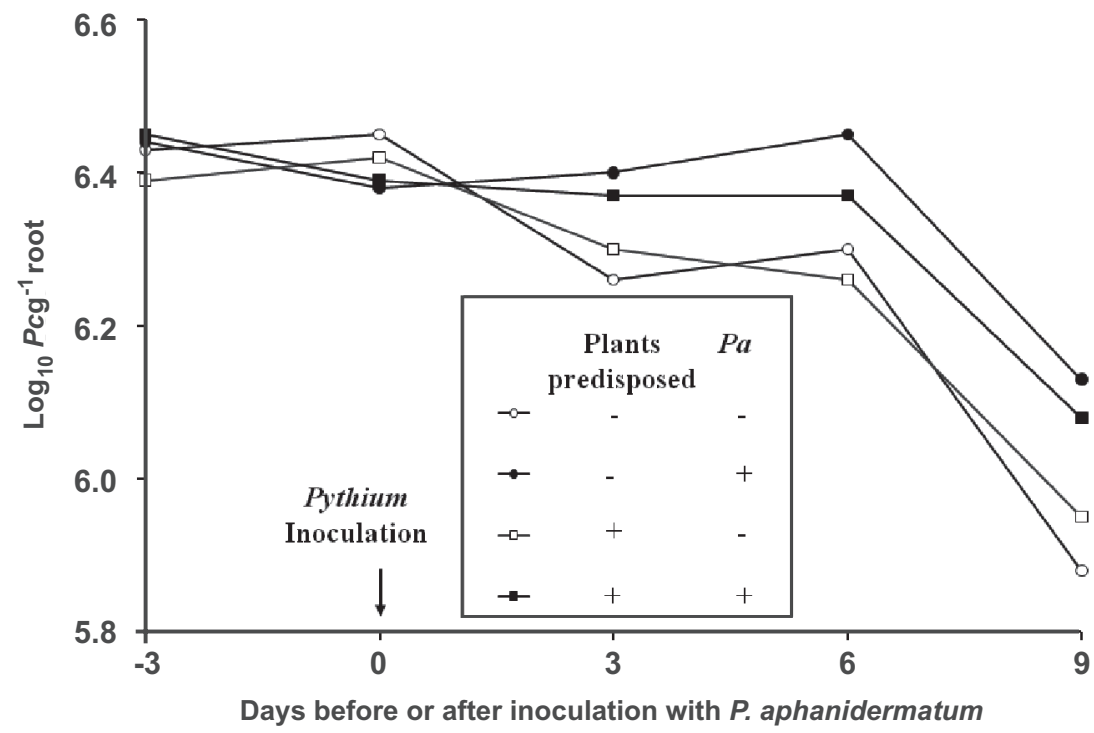

FIGURE 2 - Estimated density of Pseudomonas chlororaphis 63-28 (Pc) in hydroponic pepper roots as a function of time after application, high temperature predisposition of the plants to root rot, and root inoculation with Pythium aphanidermatum $(P a) . P c$ was applied in the nutrient solution at a final density of 1 $\mathrm{X} 10^{7} \mathrm{CFU} \mathrm{mL} \mathrm{mL}^{-1} 10$ days before roots were inoculated with $\mathrm{Pa}$. The root zone was maintained at $23^{\circ} \mathrm{C}$ for non-predisposed plants, but the temperature was increased to $33^{\circ} \mathrm{C}$ for three days prior to inoculation to predispose plants to root rot. roots. The high temperature predisposition treatment did not significantly affect density of $P$. chlororaphis at any time during the experiment except for a minor effect in inoculated plants at day 6 . At three, six and nine days after inoculation with $P$. aphanidermatum (i.e. 13, 16, and 19 days after $P$. chlororaphis was applied into the nutrient solution) density of $P$. chlororaphis in inoculated roots was significantly higher than in non-inoculated roots. Agent densities declined significantly $(\mathrm{P}=0.05)$ between days six and nine in inoculated and non-inoculated plants. At 12 days, roots not treated with $P$. chlororaphis but inoculated with $P$. aphanidermatum were substantially disintegrated, and meaningful estimates of CFUs could not be obtained.

The root browning curves of experiment 2 did not differ significantly from those of the same treatments and conditions in experiment 1. Pseudomonas chlororaphis delayed initial browning of inoculated roots by seven days for plants that were exposed to $33^{\circ} \mathrm{C}$ compared to five days for plants at a constant $23^{\circ} \mathrm{C}$. In each instance, browning did not exceed $30 \%$ when the experiment ended at 12 days after inoculation (22 days after $P$. chlororaphis was applied). 
Experiment 3. Effects of Pseudomonas chlororaphis, root zone temperature, and root inoculation with Pythium aphanidermatum on plant growth parameters

Pseudomonas chlororaphis did not significantly affect plant height, or fresh and dry mass values of the shoots and roots at seven days after application when the high temperature predisposition treatment was initiated, at 10 days when roots were inoculated with $P$. aphanidermatum, or at 13 days (three days after inoculation), but significant effects were found at 16, 19, and 22 days (six, nine and 12 days after inoculation). Significant increases in total plant leaf area were first observed at 10 days after the $P$. chlororaphis treatment (the day of inoculation). At 19 days (nine days after inoculation), the shoots and root systems of plants treated with $P$. chlororaphis generally appeared larger than those of untreated plants, regardless of the root zone temperature regime or whether the roots were inoculated with $P$. aphanidermatum (Figure 3). Root rot was markedly less severe in $P$. chlororaphis-treated plants than in untreated plants in each temperature regime.

\section{Plant height}

Plants that were not treated with $P$. chlororaphis but inoculated with $P$. aphanidermatum were significantly shorter than plants of all other treatments at six and nine days after inoculation (16 and 19 days after P. chlororaphis treatment) but not at earlier sampling times. At nine days after inoculation, plant height in given treatments of the two temperature regimes did not differ significantly (Table 1). Plants that were untreated and not inoculated with $P$. aphanidermatum averaged $26 \mathrm{~cm}$ in height. The pathogen suppressed the height of untreated plants by $8-10 \%$. The $P$. chlororaphis treatment increased plant height by $18-19 \%$ in plants not inoculated with the pathogen and by $10-11 \%$ in the inoculated plants.

\section{Total plant leaf area}

The mean total leaf area per plant was $270 \mathrm{~cm}^{2}$ when $P$. chlororaphis was applied in the nutrient solution. After seven days, when the high temperature treatment was initiated, the respective mean leaf areas of $P$. chlororaphistreated plants and untreated plants were $500 \mathrm{~cm}^{2}$ and 430 $\mathrm{cm}^{2}$ and not significantly different. After 10 days, when plants were inoculated with $P$. aphanidermatum, leaf area was significantly greater in $P$. chlororaphis-treated plants $\left(815-840 \mathrm{~cm}^{2}\right)$ than in untreated plants $\left(710-730 \mathrm{~cm}^{2}\right)$. The root-zone temperatures did not significantly affect leaf area of plants of given treatments at 10 days or at later sampling times. At 19 days (nine days after inoculation) in plants not treated with $P$. chlororaphis, leaf area was $21-25 \%$ lower in inoculated compared to non-inoculated plants (Table 1). By 19 days following application, P. chlororaphis increased leaf

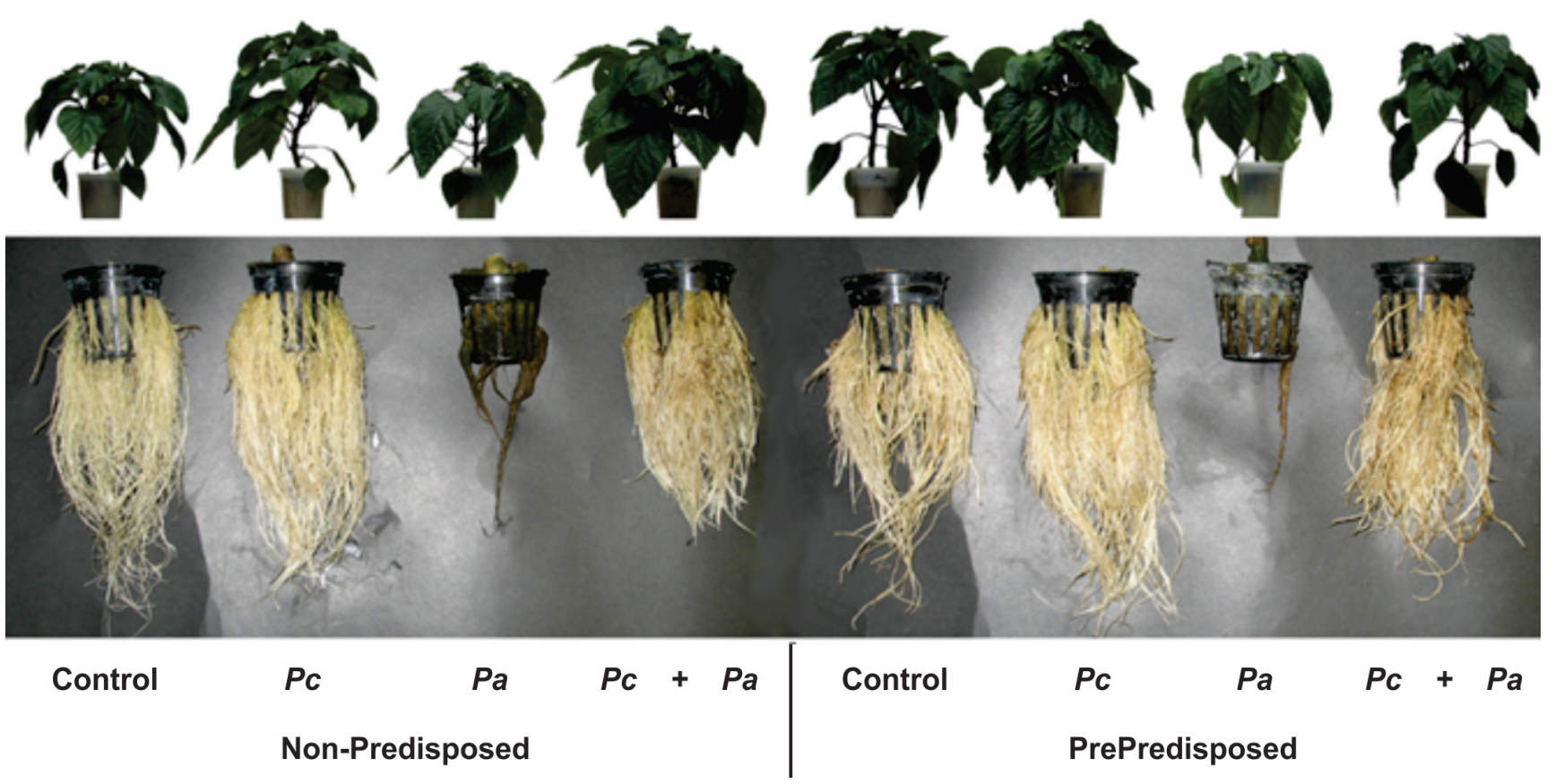

FIGURE 3 - Pictorial comparison of the effects of Pseudomonas chlororaphis 63-28 $(P c)$ and inoculation of the roots with Pythium aphanidermatum $(\mathrm{Pa})$, separately and in combination, in pepper plants that were not predisposed or predisposed to Pythium root rot. Plants were photographed at nine days after inoculation with $P a$. Pc was applied in the nutrient solution 10 days before the roots were inoculated with $\mathrm{Pa}$. The root zone of non-predisposed plants was maintained at $23^{\circ} \mathrm{C}$ and the temperature was increased to $33^{\circ} \mathrm{C}$ for three days prior to inoculation with $P a$ for predisposing the plants. 
TABLE 1 - Growth components of hydroponic peppers that were treated or not treated with Pseudomonas chlororaphis (Pc), predisposed or not predisposed to root rot by high temperature treatment, and inoculated or not inoculated with Pythium aphanidermatum (Pa). Data are presented for day 9 after inoculation with $P$. aphanidermatum (i.e. 19 days after application of $P c$ )

\begin{tabular}{ccccccccc}
\hline \hline $\boldsymbol{P c}$ & $\begin{array}{c}\text { Plants } \\
\text { predisposed }\end{array}$ & $\boldsymbol{P a}$ & $\begin{array}{c}\text { Plant height } \\
\mathbf{( c m})\end{array}$ & $\begin{array}{c}\text { Total leaf area } \\
\left(\mathbf{c m}^{2}\right)\end{array}$ & $\begin{array}{c}\text { Shoot fresh } \\
\text { mass } \mathbf{( g )}\end{array}$ & $\begin{array}{c}\text { Shoot dry } \\
\text { mass } \mathbf{( g )}\end{array}$ & $\begin{array}{c}\text { Root fresh } \\
\text { mass } \mathbf{( g )}\end{array}$ & $\begin{array}{c}\text { Root dry mass } \\
(\mathbf{g})\end{array}$ \\
\hline- & - & - & $26.0 \mathrm{c}$ & $1404 \mathrm{c}$ & $62.9 \mathrm{c}$ & $5.4 \mathrm{c}$ & $11.8 \mathrm{~b}$ & $1.0 \mathrm{~b}$ \\
+ & - & - & $31.0 \mathrm{a}$ & $1727 \mathrm{a}$ & $70.6 \mathrm{a}$ & $6.3 \mathrm{a}$ & $13.8 \mathrm{a}$ & $1.2 \mathrm{a}$ \\
- & - & + & $23.3 \mathrm{~d}$ & $1114 \mathrm{~d}$ & $54.1 \mathrm{~d}$ & $4.8 \mathrm{~d}$ & $10.1 \mathrm{c}$ & $0.9 \mathrm{c}$ \\
+ & - & + & $28.3 \mathrm{~b}$ & $1621 \mathrm{ab}$ & $61.6 \mathrm{c}$ & $5.4 \mathrm{c}$ & $13.0 \mathrm{ab}$ & $1.1 \mathrm{ab}$ \\
- & + & - & $25.7 \mathrm{c}$ & $1439 \mathrm{c}$ & $60.4 \mathrm{c}$ & $5.3 \mathrm{c}$ & $11.7 \mathrm{~b}$ & $1.0 \mathrm{~b}$ \\
+ & + & - & $30.7 \mathrm{a}$ & $1695 \mathrm{a}$ & $72.6 \mathrm{a}$ & $6.4 \mathrm{a}$ & $13.6 \mathrm{a}$ & $1.2 \mathrm{a}$ \\
+ & + & + & $23.7 \mathrm{~d}$ & $1075 \mathrm{~d}$ & $51.3 \mathrm{~d}$ & $4.8 \mathrm{~d}$ & $9.1 \mathrm{c}$ & $0.8 \mathrm{c}$ \\
+ & + & + & $28.7 \mathrm{~b}$ & $1513 \mathrm{bc}$ & $62.2 \mathrm{bc}$ & $5.6 \mathrm{bc}$ & $12.6 \mathrm{~b}$ & $1.1 \mathrm{~b}$ \\
\hline
\end{tabular}

Treatment means in a column followed by the same letter do not differ significantly by ANOVA ( $\mathrm{P}=0.05$; LSD).

area by $18-23 \%$ in plants not inoculated with the pathogen and by $45-58 \%$ in the inoculated plants.

\section{Fresh mass and dry mass}

At 10 days after the $P$. chlororaphis treatment, when plants were inoculated with $P$. aphanidermatum, values for shoot fresh mass, shoot dry mass, root fresh mass and root dry mass, respectively, ranged from 39.05$42.80 \mathrm{~g}, 3.53-3.66 \mathrm{~g}, 6.35-7.07 \mathrm{~g}$ and 0.55-0.61 $\mathrm{g}$ and did not differ significantly among treatments. Values of the respective variables also were not significantly different on day 13 (three days after inoculation). At day 16 (six days after inoculation), no significant effects were found of $P$. aphanidermatum on fresh mass or dry mass values of shoots or roots of plants not treated with $P$. chlororaphis in either temperature regime, and values for the two regimes did not differ significantly. At that time in non-inoculated plants, $P$. chlororaphis significantly increased shoot fresh mass and dry mass by $4 \%$ and $5 \%$ respectively when the root zone was constant at $23^{\circ} \mathrm{C}$, and by $10 \%$ and $12 \%$ in the high temperature regime. In the inoculated plants, values of the respective variables and temperature conditions were increased by $7 \%$ and $9 \%$ and by $7 \%$ and $10 \%$. In the high temperature regime, the $P$. chlororaphis treatment respectively increased root fresh mass and dry mass by $14 \%$ and $11 \%$ in plants inoculated with $P$. aphanidermatum, and by $12 \%$ and $10 \%$ in non-inoculated plants, but no treatment effects were observed in plants kept at a constant $23^{\circ} \mathrm{C}$.

Major effects of the $P$. chlororaphis treatment and $P$. aphanidermatum on fresh mass and dry mass of the shoots and roots were observed at 19 days after the treatment (nine days after inoculation) (Table 1).The values for plants of the high temperature predisposition treatment were not significantly different from those at a constant $23^{\circ} \mathrm{C}$. In the absence of $P$. chlororaphis, $P$. aphanidermatum respectively suppressed shoot fresh mass and dry mass by $14-15 \%$ and $9-11 \%$, and root fresh mass and dry mass by $14-22 \%$ and $16-22 \%$. In plants treated with $P$. chlororaphis but not inoculated with $P$. aphanidermatum, shoot fresh mass was increased by $12-20 \%$, shoot dry mass by $17-21 \%$, root fresh mass by $16-17 \%$ and root dry mass by $20 \%$ compared to the untreated controls. In plants treated with $P$. chlororaphis and inoculated with $P$. aphanidermatum, shoot fresh mass was increased by $14-21 \%$, shoot dry mass by $13-17 \%$, root fresh mass by $29-38 \%$ and root dry mass by $22-38 \%$ when compared to inoculated control plants that were not treated with P. chlororaphis.

\section{Experiment 4: Effects of Pseudomonas chlororaphis, root zone temperature, and root inoculation with Pythium aphanidermatum on leaf expansion}

The area ofleaf 12 was $47-49 \mathrm{~cm}^{2}$ when P. chlororaphis was applied into the nutrient solution (Figure 4). Ten days later, when plants were inoculated with $P$. aphanidermatum, the area of leaf 12 in P. chlororaphis -treated and untreated plants did not differ significantly whether or not the roots were exposed to high pre-inoculation temperature. During the subsequent 12 days, leaf 12 progressively expanded in all treatments except in inoculated plants that were not treated P. chlororaphis. In respective plants of the high temperature predisposition treatment and in non-predisposed plants, leaf 12 ceased or almost ceased to expand within 2 and 5 days after inoculation, which in each case coincided with initial root browning.

Treatment effects on the expansion of leaf 12 were based on values for area under the leaf expansion curve (AULEC) for the 12-day period immediately after plants were inoculated with P. aphanidermatum. Leaf areas on day 0 did not differ significantly among treatments and were used as base values for AULEC estimations. In plants not inoculated with the pathogen, the $P$. chlororaphis treatment significantly increased AULEC values from 332 to 485 units and from 319 to 381 units, respectively, in non-predisposed and predisposed plants. In inoculated plants that were not predisposed to root rot (constant $23^{\circ} \mathrm{C}$ ), P. chlororaphis significantly increased the AULEC from 94 to 430 units. Respective values for plants that were predisposed at $33^{\circ} \mathrm{C}$ were 38 and 394 units. In general, expansion of leaf 12 was 


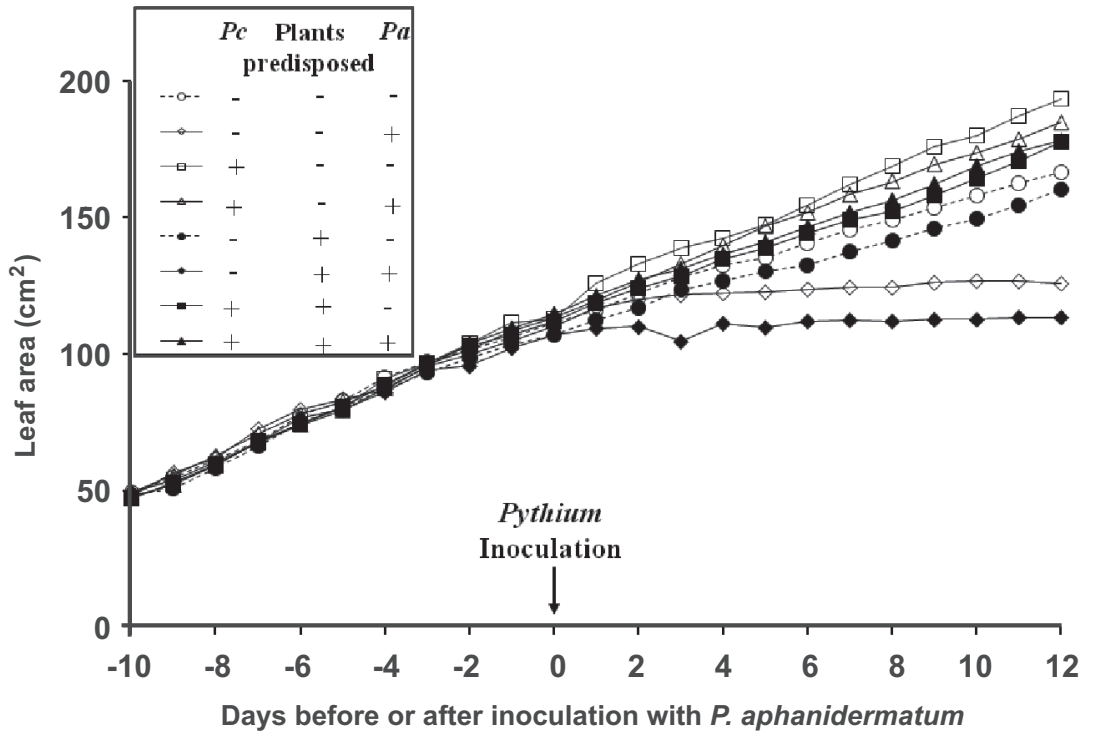

FIGURE 4 - Area expansion of leaf 12 in pepper plants as a function of Pseudomonas chlororaphis $(P c)$ application in the nutrient solution, high temperature predisposition of the plants to Pythium root rot, and inoculation with Pythium aphanidermatum $(P a) . P c$ was applied 10 days before the roots were inoculated with $P a$. The root zone was maintained at $23{ }^{\circ} \mathrm{C}$ for nonpredisposed plants but the temperature was increased to $33^{\circ} \mathrm{C}$ for three days prior to inoculation with $\mathrm{Pa}$ for predisposition of plants to root rot. marginally lower following exposure of the roots to $33^{\circ} \mathrm{C}$ compared to a constant $23^{\circ} \mathrm{C}$. Less than $40 \%$ of the roots were brown in P. chlororaphis-treated plants on day 12 .

\section{DISCUSSION}

The data provide a quantitative perspective of $P$. chlororaphis 63-28 in relation to progress of root rot and growth responses of peppers following high temperature predisposition compared to no pre-disposition of the roots to browning caused by $P$. aphanidermatum. Pseudomonas chlororaphis 63-28 applied in the plant nutrient solution

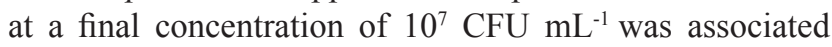
profusely and persistently with the pepper roots, delayed development of Pythium root rot, and markedly promoted growth of plants inoculated with $P$. aphanidermatum and of non-inoculated plants. In general, the agent performed as effectively in roots that were predisposed to precocious browning by the high temperature episode (Sopher \& Sutton, 2009) as in non-predisposed roots maintained at a constant $23^{\circ} \mathrm{C}$.

The final density of $P$. chlororaphis applied in the nutrient solution 10 days before roots were inoculated with P. aphanidermatum was a critical factor affecting the ability of the agent to suppress root rot. A density of $10^{7} \mathrm{CFU} \mathrm{mL}^{-1}$ solution delayed root browning more effectively than did the higher or lower densities when the root zone was kept at a constant $23^{\circ} \mathrm{C}$, while densities of $10^{6}, 10^{7}$ and $10^{8} \mathrm{CFU}$ $\mathrm{mL}^{-1}$ solution were equally superior in roots exposed to high temperature predisposition (Figure 1). Taken together, the data indicated that a final density of $10^{7} \mathrm{CFU} \mathrm{mL} \mathrm{m}^{-1}$ solution was near optimal for root rot control. Previous reports of inoculum density of $P$. chlororaphis in relation to Pythium root rot are lacking. However, Khan et al. (2003) and Chatterton et al. (2004) employed a final density of $10^{7} \mathrm{CFU}$
P. chlororaphis TX-1 mL $\mathrm{m}^{-1}$ solution in pepper experiments, while Zheng et al. (2000) used $10^{5}$ CFU P. chlororaphis JZ-24 $\mathrm{mL}^{-1}$ solution in cucumber studies. Densities near

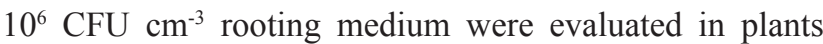
grown in rock wool (Rankin \& Paulitz, 1994; McCullagh et al., 1996) and peat-based substrates (Gagné et al., 1993). Our findings that the effectiveness of $P$. chlororaphis against root browning was much less when applied at $10^{5}$ or $10^{4} \mathrm{CFU} \mathrm{mL}^{-1}$ compared to $10^{6}$ or $10^{7} \mathrm{CFU} \mathrm{mL}^{-1}$ were consistent with the concept that a density threshold of a microbial agent is required for effective disease suppression (Raaijmakers et al., 1995). In this concept, small changes in cell density above or below a critical threshold level markedly affect agent effectiveness, a phenomenon which may be related to quorum sensing in the microbial cell populations (von Bodman et al., 2003). Quorum sensing involves chemical communication among bacteria and allows bacterial populations to alter behavior in response to the number present in the community (Waters \& Bassler, 2005). Effectiveness of $P$. chlororaphis may depend on maintaining adequate distribution of cells at densities above threshold levels in diverse niches on or within the roots. The finding that the effectiveness of $P$. chlororaphis was lower when applied at $10^{8} \mathrm{CFU} \mathrm{mL} \mathrm{m}^{-1}$ compared to $10^{7} \mathrm{CFU}$ $\mathrm{mL}^{-1}$ in plants maintained at $23^{\circ} \mathrm{C}$ was possibly related to quorum sensing, and suggested that densities in excess of $10^{7} \mathrm{CFU} \mathrm{mL} \mathrm{mL}^{-1}$ solution may be counterproductive for root rot management.

The high density of $P$. chlororaphis 63-28 found in roots (approximately 1-6 x 10 ${ }^{6} \mathrm{CFU} \mathrm{g}^{-1}$ fresh roots) at seven to 19 days after treatment in the two temperature regimes indicated that the final treatment density of $10^{7}$ $\mathrm{CFU} \mathrm{mL} \mathrm{mL}^{-1}$ nutrient solution was sufficient for establishing a durable association of the strain with the growing root systems. The recovered densities were higher than reported 
for P. chlororaphis TX-1 by Khan et al. (2003) but similar to those found for strain TX-1 by Chatterton et al. (2004). The observation that a high density of $P$. chlororaphis was sustained for longer in roots inoculated with $P$. aphanidermatum than in non-inoculated roots agreed with findings of Chatterton et al. (2004) for P. chlororaphis TX-1, and supports the notion that diseased roots are more conducive to growth and survival of $P$. chlororaphis than are healthy roots. The higher density of $P$. chlororaphis 63-28 in the diseased roots may be related to an increased partitioning of photosynthates to the roots and increased exudation of carbon compounds from the roots in response to root infection by $P$. aphanidermatum (Kamilova et al., 2006; Ortiz-Uribe, 2007). The moderate declines in density of $P$. chlororaphis observed at 19 days after treatment coincided with initial flowering of the peppers and so were possibly associated with flowering-related changes in host physiology. The estimates of $P$. chlororaphis CFUs should be interpreted with recognition that portions of the cell populations were possibly viable but not culturable (Kell et al., 1998).

The disease progress curves indicated that $P$. chlororaphis delayed root browning for three to six days following inoculation with $P$. aphanidermatum, but did not markedly affect the rate of increase in brown roots as indicated by the slopes of the browning curves. In inoculated plants that were not treated with $P$. chlororaphis, the preinoculation high temperature treatment advanced root browning by several days, but also did not generally affect the slopes and shapes of the browning curves. In effect, the $P$. chlororaphis treatment lengthened the biotrophic phase of Pythium root rot and delayed the necrotrophic phase, and the reverse was the case for pre-inoculation high temperature (Sutton et al., 2006; Sopher \& Sutton, 2009). The clustering of the root browning curves of $P$. chlororaphis-treated plants at 9-12 days after inoculation (Fig. 1) indicated that $P$. chlororaphis effectively re-mediated high temperature predisposition of the roots to precocious browning caused by $P$. aphanidermatum.

Pseudomonas chlororaphis 63-28 evoked major growth increases in the roots and shoots of pepper plants that were not inoculated with $P$. aphanidermatum. In summary, following an initial lapse of 7-10 to 10-13 days, the single application of $P$. chlororaphis progressively increased the growth parameters of the healthy vegetative peppers until the experiment was ended on day 22, despite the high nutrient availability in the root zone. Given the high density of $P$. chlororaphis in the roots at day 22, a potential existed for continued growth promotion without an additional treatment.

In plants inoculated with $P$. aphanidermatum, growth increases in response to $P$. chlororaphis, expressed on a percentage basis, were in several instances greater than in the non-inoculated plants. The $P$. chlororaphis treatment substantially mitigated the destructive effects of $P$. aphanidermatum on the growth components of the peppers, including the early cessation of leaf expansion (Figure 4). The major effects evoked by $P$. chlororaphis on root growth probably resulted in large part from the suppression of browning and growth reduction caused by the pathogen in the roots, but direct growth promotion may also have played a role. The markedly greater responses to P. chlororaphis observed for leaf area than for shoot fresh mass and dry mass in the inoculated plants suggest that the plants partitioned proportionately more carbon resources to the leaves than the stems (Figure 4 and Table 1).

Growth of the young leaf (leaf 12) was a sensitive marker of root infection by $P$. aphanidermatum and of plant growth promotion by $P$. chlororaphis, but not of stress associated with the high temperature episode in the root zone (Figure 4). In the absence of P. chlororaphis, the cessation or near cessation in growth of leaf 12 in less than two days after inoculation in plants of the high temperature regime, and within five days for plants at a constant $23^{\circ} \mathrm{C}$, contrasted with the continued rapid growth of the equivalent leaf in the non-inoculated control plants (Figure 4). The findings for leaf 12 were consistent with observations in hydroponicallygrown snapdragons inoculated with the same strain of $P$. aphanidermatum (Sutton et al., 2006; Ortiz-Uribe, 2007). Growth measurements of leaf 12 also provide a relatively non-intrusive means for quantitative tracking of the effects of $P$. chlororaphis on canopy development in healthy and inoculated plants. The measurements did not, however, detect changes induced in the roots by the high temperature treatment which resulted in predisposition of inoculated roots to browning (Sopher \& Sutton, 2009).

While the temperatures, $\mathrm{pH}$, dissolved oxygen levels, and composition of the nutrient solution in the single-plant hydroponic units were representative of those in pepper crops in Ontario, several other conditions were different, and may warrant consideration should $P$. chlororaphis 6328 be developed for commercial use. The high turbulence of the nutrient solution arising from aeration bubblers in the hydroponic units probably contrasts with turbulence of solutions of commercial crops that percolate through rooting matrices such as rock wool and coconut fiber (Sutton et al., 2006). Zoospores of $P$. aphanidermatum readily lose flagella and thus motility under turbulent conditions (Chatterton et al., 2004; Sutton et al., 2006), but possible effects of turbulence on $P$. chlororaphis, such as its ability to associate with roots, have not been reported. Susceptibility to Pythium root rot is generally high when plants are young and vegetative, as in the present studies, but generally decreases with age, notably at the flowering and fruiting stages, although young roots are highly susceptible at all stages (Kamoun et al., 1999; Martin \& Loper, 1999; Sutton et al., 2006; Ortiz-Uribe, 2007). The intensity of PAR, a key factor influencing productivity and levels of carbon compounds in the root zone (Ortiz-Uribe, 2007), was much lower in the growth room compared to daytime levels in commercial greenhouses. The abrupt exposure of roots to a high zoospore density of $P$. aphanidermatum during 
Quantitative relationships of Pseudomonas chlororaphis 63-28 to Pythium root rot...

inoculations probably differed substantially from zoospore density dynamics in hydroponic crops. Implications of the foregoing and other factors in the epidemics and control of Pythium root rot in commercial crops were considered earlier (Sutton et al., 2006).

The persistent association of $P$. chlororaphis 6328 with the roots, the suppression of root browning, and the plant growth promotion by the agent in the pepper plants suggest that the strain has substantial potential for enhancing the health and productivity of hydroponic pepper crops. The strong growth promotion in the absence of $P$. aphanidermatum may justify its use as a root-zone inoculant in healthy crops, while the strong suppression of root rot underscored its value as a biological control agent. Tests are needed under representative crop conditions to determine the performance of strain 63-28 in relation to pepper productivity, such as earliness of fruiting and marketable fruit yield, and as functions of treatment protocols such as timing and mode of application. The growth effects of strain 63-28 may require that adjustments be made in levels of nitrogen or other elements in the plant nutrient solution. Results of the present study and beneficial effects reported previously (Gagné et al., 1993; McCullagh et al., 1996; Liu et al., 2003; Liu et al., 2007; Corrêa et al., 2010) suggest that strain 63-28 has substantial value as a versatile inoculant and control agent against Pythium root rot in a range of hydroponic crops.

\section{ACKNOWLEDGEMENTS}

This research was supported by the Natural Sciences and Engineering Research Council of Canada (Discovery Grant to the second author).

\section{REFERENCES}

Chatterton S (2002) Biological control of Pythium root rot of bell pepper (Capsicum annuum L.) in a small-scale hydroponic system. M.Sc. Thesis. University of Guelph. Guelph, Ontario, Canada.

Chatterton S, Sutton JC, Boland GJ (2004) Timing Pseudomonas chlororaphis applications to control Pythium aphanidermatum, Pythium dissotocum, and root rot in hydroponic peppers. Biological Control 30:360-373.

Corrêa EB, Bettiol W (2009) Controle da podridão de raiz e promoção de crescimento em hidroponia com bactérias. In: Bettiol W, Morandi MAB (Eds.) Biocontrole de doenças de plantas: uso e perspectivas. Jaguariúna SP. Embrapa Meio Ambiente. pp. 225238.

Corrêa, EB, Bettiol W, Sutton JC ( 2010) Controle biológico da podridão radicular (Pythium aphanidermatum) e promoção de crescimento por Pseudomonas chlororaphis 63-28 e Bacillus subtilis GB-03 em alface hidropônica. Summa Phytopathologica 36:275-281.

Gagné S, Dehbi L, Le Quéré D, Cayer F, Morin J-L., Lemay R, Fournier N (1993) Increase of greenhouse tomato fruit yields by plant growth-promoting rhizobacteria (PGPR) inoculated into the peat based growing media. Soil Biology and Biochemistry 25:269-272.

Johnson JL, Palleroni NJ (1989) Deoxyribonucleic acid similarities among Pseudomonas species. International Journal of Systematic Bacteriology 39:230-235.

Kamilova F, Kravchenko LV, Shaposhnikov AI, Azarova T, Makarova N, Lugtenberg B (2006) Organic acids, sugars, and 1-tryptophane in exudates of vegetables growing on stonewool and their effects on activities of rhizosphere bacteria. Molecular PlantMicrobe Interactions 19:320-256.

Kamoun, S, Huitema E, Vleeshouwers VGAA (1999) Resistance to oomycetes: a general role for the hypersensitive response? Trends in Plant Science 4:196-200.

Kell DB, Kaprelyants AS, Weichart DH, Harwood C, Barer MR (1998) Viability and activity in readily culturable bacteria: a review and discussion of the practical issues. Antonie van Leeuwenhoek 73:169-187.

Khan A, Sutton JC, Grodzinski B (2003) Effects of Pseudomonas chlororaphis on Pythium aphanidermatum and root rot in peppers grown in small-scale hydroponic troughs. Biocontrol Science Technology 13:615-630.

Liu W, Sutton JC, Huang R (2003) Effectiveness of microbial agents to protect against Pythium root rot in hydroponic cucumber. In: Biological and cultural tests for control of plant diseases. Report 18:V027. Saint Paul MN. APS Press.

Liu W, Sutton JC, Grodzinski B, Kloepper, JW, Reddy MS (2007) Biological control of Pythium root rot of chrysanthemum in smallscale hydroponic units. Phytoparasitica 35:59.

Martin FN, Loper JE (1999) Soilborne plant diseases caused by Pythium spp.: ecology, epidemiology, and prospects for biological control. Critical Reviews in Plant Sciences 18:111-181.

McCullagh M, Utkehede R, Menzies JG, Punja ZK, Paulitz TC (1996) Evaluation of plant growth-promoting rhizobacteria for biological control of Pythium root rot of cucumbers grown in rockwool and effects on yield. European Journal of Plant Pathology 102:747-755.

Ortiz-Uribe N (2007) Morphological and physiological changes of snapdragon (Antirrhinum majus L.) after inoculation with Pythium aphanidermatum. PhD. Thesis, University of Guelph, Guelph, Ontario, Canada.

Owen-Going TN, Sutton JC, Grodzinski B (2003) Relationships of Pythium isolates and pepper plants in single-plant hydroponic units. Canadian Journal of Plant Pathology 25:155-167.

Paulitz TC, Bélanger RR (2001) Biological control in greenhouse systems. Annual Review of Phytopathology 39:103-133.

Raaijmakers JM, Leeman M, van Oorschot MP, van der Sluis I, Schippers B, Bakker PAHM (1995) Dose-response relationships in biological control of fusarium wilt of radish by Pseudomonas spp. Phytopathology 85:1075-1081.

Rankin R, Paulitz TC (1994) Evaluation of rhizobacteria for biological control of Pythium root rot of greenhouse cucumbers in hydroponic culture. Plant Disease 78:447-451.

Sopher CR, Sutton JC (2009) Relationships of pre-inoculation high temperature to root browning caused by Pythium aphanidermatum in hydroponically-grown sweet pepper. Tropical Plant Pathology 34:361-369. 
Sutton JC, Sopher CR, Owen-Going TN, Liu W, Grodzinski B, Hall JC, Benchimol RL (2006) Etiology and epidemiology of Pythium root rot in hydroponic crops: current knowledge and perspectives. Summa Phytopathologica 32:307-321.

Sutton JC, Liu W, Ma J, Brown, WG, Stewart JF, Walker GD (2008) Evaluation of the fungal endophyte Clonostachys rosea as an inoculant to enhance growth, fitness and productivity of crop plants. Acta Horticulturae (ISHS) 782:279-286

von Bodman SB, Bauer WD, Coplin DL (2003) Quorum sensing in plant pathogenic bacteria. Annual Review of Plant Patholology 41:455-482.

Waters CM, Bassler BL (2005) Quorum sensing: cell-tocell communication in bacteria. Annual Review of Cell and Developmental Biology 21:319-346.

Zheng J, Sutton JC, Yu H (2000) Interactions among Pythium aphanidermatum, roots, root mucilage, and microbial agents in hydroponic cucumbers. Canadian Journal of Plant Pathology 22:368-379.

TPP 262 - Received 27 February 2011 - Accepted 22 August 2011

Section Editor: Wagner Bettiol 